\title{
„Zielone pisanie”, „zielone czytanie". Humanistyka ekologiczna jako projekt badań literaturoznawczych
}

\author{
Wiesława Tomaszewska \\ Wydział Nauk Humanistycznych, Uniwersytet Kardynała Stefana Wyszyńskiego w Warszawie \\ ul. Dewajtis 5, 01-815 Warszawa \\ wtomaszewska@uksw.edu.pl
}

\begin{abstract}
Streszczenie
Artykuł omawia jedną z nowych metodologii w badaniach literaturoznawczych, którą jest humanistyka ekologiczna. Odwołując się do tekstów teoretycznych, autorka polemicznie analizuje ich główne idee. W tym duchu komentuje interpretację dzieł literackich, prowadzonych zgodnie z metodologią proponowaną przez humanistykę ekologiczną, skupiając się na szkicu o powieści Antoniego Sygietyńskiego Na skałach Calvados (1884). Wskazuje na „zielone pisanie" jako na stałą praktykę twórców dzieł literackich, stawiając tezę, że literaturze można przypisać również cechę prekursorstwa w dziedzinie ekologii.
\end{abstract}

\section{Stowa kluczowe}

humanistyka ekologiczna, biohumanistyka, ekologiczny paradygmat w literaturoznawstwie

\section{W stronę humanistyki ekologicznej}

Problematykę związku literatury z przyrodą, interpretacji obrazów przyrody w badaniach nad literaturą, podejmuje zarówno tradycja literacka, jak i teoria badań nad literaturą i to od czasów najdawniejszych poczynając, od literatury biblijnej, od starożytności greckiej i łacińskiej, poprzez literatury narodowe, aż do współczesności. I nic w tym dziwnego, skoro już na początku wieku XII cudzoziemiec Gall Anonim oddając genius loci ziem polskich, podkreślił zarówno piękno polskiej przyrody, jak i idealnie harmonijny związek pomiędzy przyrodą a człowiekiem. Pisał następująco: „Kraj to wprawdzie bardzo lesisty, ale niemało przecież obfituje w złoto i srebro, chleb i mięso, w ryby i miód [...].
Kraj, gdzie powietrze zdrowe, rola żyzna, las miodopłynny, wody rybne, rycerze wojowniczy, wieśniacy pracowici, konie wytrzymałe, woły chętne do orki, krowy mleczne, owce wełniste" (Gall Anonim 1965: 11). Mimo gęsto rozsianych w dziełach literackich obrazów przyrody, zawierających znakomite artystycznie ujęcia natury, bywa i tak, że 'opisy przyrody' nie są przez czytelników odbierane zbyt entuzjastycznie. W kompozycji tekstu pozostają w cieniu, jako elementy dalszoplanowe, jako tekstowe dłużyzny w wartkim przebiegu fabularnych zdarzeń.

W przywracaniu rangi opisom przyrody w literaturoznawczych praktykach interpretacyjnych istotnym momentem były prace z zakresu estetyki (Władysława 
Tatarkiewicza, Stanisława Ossowskiego), filozofii człowieka (szkice Romana Ingardena w Książeczce o człowieku), a także prace teoretycznoliterackie z wynikami badań nad opisem jako jedną z literackich form deskryptywnych, które organizują także "zieloną" czasoprzestrzeń w utworze (tu: Sławiński, Wysłouch, Korwin-Piotrowska). Wspomniane prace, a w pewnym stopniu również wzrastające w społeczeństwie nastawienie na ekologię, upowszechnienie się edukacji ekologicznej ${ }^{1}$, niewątpliwie przyczyniły się do budowania świadomości, że opis przyrody jest niezbywalnym elementem w sieci tekstowych znaczeń, że w dziele literackim, jako „synchronicznie zamkniętej strukturze" (Łotman 1984: 51), liczy się każdy poziom tekstu. Przywrócono więc opisom przyrody należną im wysoką rangę, choćby w konkretnym utworze prezentowały się one jak najskromniej. Wydarzenia w dziele literackim nigdy nie rozgrywają się w przestrzeni asemantycznej, a przyroda nie jest li tylko ozdobnym tłem czy balastem fabularnym, ale kompozycyjnie wyodrębnialnym,

1 'Ekologia' to neologizm utworzony na użytek nauk przyrodniczych przez Ernesta Haeckla w 1886 r.: „Pod pojęciem ekologii rozumiemy ogólną naukę o stosunkach organizmu do otaczającego środowiska zewnętrznego. Do tego ostatniego zaliczyć możemy w najszerszym znaczeniu wszystkie warunki istnienia" (Tenże, Generelle Morphologie der Organismen, Bd. 1-2, Berlin 1866, Bd.2, s. 286 (Wróblewski 2004: 155). Jak słusznie zauważa się, słowo to, niezwykle dziś produktywne, „Przekroczyło granicę słownika nauk przyrodniczych, wkroczyło do humanistyki i nauk społecznych" (Wróblewski 2004: 153). Wróblewski wyróżnia sześć znaczeń słowa 'ekologia', z których dla nauk humanistycznych, także dla przedstawianych poniżej koncepcji humanistyki ekologicznej (także 'ekologii kultury'), najbardziej znaczace jest znaczenie piąte, zgodnie z którym słowo 'ekologia' oznacza „Światopogląd, ideologie ruchów ekologicznych zaangażowanych w ochronę środowiska. W literaturze na oznaczenie światopoglądu i ideologii używany jest także termin „ekologizm” lub „enwironmentalizm” (Wróblewski 2004: 155), z uwzględnieniem „tzw. momentu ekologicznego (czyli relacji człowiekśrodowisko) w poznawaniu rzeczywistości (Wróblewski 2004: 158, Szumski 1995: 15). artystycznie wykreowanym segmentem tekstu. Utwory literackie, dzieła filmowe, muzyczne i malarskie, kulturowy dorobek ludzkości, dowodzą, że przyroda nigdy nie stanowiła świata izolowanego względem człowieka, że człowiek od najdawniejszych czasów bytował w łączności z przyrodą i dlatego słusznie humanistyka ekologiczna (ekohumanistyka, ekoposthumanistyka) podkreśliła fakt bytowania człowieka w otoczeniu natury.

Mówiąc bardzo ogólnie, humanistyka ekologiczna ma ambicje bycia nową metodologią w badaniach literaturo- i kulturoznawczych. To jest moment pozytywny z powodów czysto pragmatycznych, że oto wśród rozmaitych metodologii jest i ta, pożyteczna, badawczo niezwykle atrakcyjna. Odpowiadając na potrzeby chwili, wyrasta ona z dziedzictwa intelektualnego i kulturowego ludzkości, z całej tradycji literackiej. Zarazem jednak na poziomie treści deklaratywnych humanistyka ekologiczna proponuje takie rozwiązania, które to dziedzictwo i tę tradycję expressis verbis podważają. Odpowiedzią na ujawniany tam ton polemiki jest niniejszy artykuł, w którym najpierw przedstawię punkty sporne w ekohumanistycznym projekcie, następnie omówię interpretację dzieła literackiego dokonaną zgodnie z ekohumanistycznym projektem, a kolejno - wskażę na „zielone pisanie” jako na stałą praktykę twórców dzieł literackich.

\section{Glówne idee ekohumanistycznego projektu}

W literaturze, zwanej piękną (litterare humaniores, fr. belles-lettres ${ }^{2}$, pojmowano

2 W filozofii, od starożytności począwszy, zazwyczaj przeciwstawia się rzeczywistość przyrodniczą rzeczywistości ludzkiej, naturę - kulturze, by przywołać tytułem przykładu przeciwstawianie jońskich filozofów przyrody Sokratesowi. Podobnie w nauce: w kręgu niemieckojęzycznym odróżnia się Naturwissenschaften od Geisteswissenschaften, w kręgu języka angielskiego - sciences od letters, humanities, w kręgu języka francuskiego - sciences od lettres. Również w języku polskim odróżnia się i przeciwstawia nauki przyrodnicze naukom hu- 
przyrodę jako pozostającą w bliskiej relacji z człowiekiem, w ostatnich zaś latach jest to w humanistyce nurt badań określany przez jego promotorów jako „zwrot ekologiczny". Humanistyka ekologiczna została bardzo dobrze przyjęta w środowisku literaturoznawczym, z powodzeniem rozwijana w piśmiennictwie naukowym. W jej kręgu stosuje się pozytywną semantycznie, zabarwioną emocjonalnie metaforę: „zielone pisanie”, „zielone czytanie" i „zielone badania kulturowe" (green cultural studies) (Domańska 2013a: 17, Kronenberg 2014: 295299), określające idee praktyki analitycznej i interpretacyjnej, literaturo- i kulturoznawczej, pasujące do ogółu praktyk twórczych w pisarstwie artystycznym. I choć przytoczone tu wyrażenia zda się ograniczają sens, ponieważ sugerują związek z roślinnością, tego rodzaju badania są ukierunkowane na całość natury i mają w zamyśle teoretycznym charakter holistyczny w sensie zasięgu planetarnego; w jego obrębie ma funkcjonować empatyczna „wspólnota wielogatunkowa", silnie skoncentrowana na ludziach i nie-ludziach, na "wszelkich formach życia (zarówno ożywionych, jak i nieożywionych)" (Piechota 2015: 192). W badaniach prowadzonych przez humanistykę ekologiczną, także na poziomie metanaukowym, mocny akcent pada na ich opozycyjny charakter i to nie tylko względem dotychczasowych badań literaturoznawczych nad przyrodą, ale także na dążności do przeorientowania badawczego myślenia o naturze. Sedno zmiany to arbitralna zmiana perspektywy $-\mathrm{z}$ antropocentrycznej na nieantropocentryczną.

manistycznym i społecznym. Próbę holistycznego ujęcia znajdujemy w ekofilozofii i sozologii (Dołęga 2006a, Dołęga 2006b). Konsekwencją tego jest np. ujmowanie świata w dwóch konkurujących ze sobą perspektywach: antropocentrycznej i biocentrycznej. Nadużyciem byłoby jednak dopatrywanie się wszędzie, zwłaszcza w twórczości literackiej, opowiadania się z konieczności za jedną z tych perspektyw, gdy częściej świat przedstawiony w dziele jest konstytuowany poza perspektywą antropo-i biocenotyczną, co ujawni się w dalszej części artykułu.
Kluczowym tekstem dla zawiązania humanistyki ekologicznej na gruncie polskim, promującym metodologię z określonymi założeniami, był szkic Ewy Domańskiej $\mathrm{Hu}$ manistyka ekologiczna, opublikowany na łamach czasopisma „Teksty Drugie” (2013) ${ }^{3}$. Sięgając do historii omawianej metody, autorka podaje informację, iż „Za początek rozwoju humanistyki ekologicznej przyjmuje się rok 1980, kiedy ukazała się książka Carolyn Merchant The Death of Nature. Women, Ecology and the Scientific Revolution" (Domańska 2013a: 18), by następnie wyjaśnić, że „ten szybko rozwijający się od końca lat 9o. nurt humanistyki ekologicznej, [...] buduje się w optyce posthumanistycznej krytyki antropocentryzmu, eurocentryzmu i geocentryzmu, a także podkreśla zasadność tworzenia wiedzy komplementarnej i inkluzywnej powstającej z połączenia nauk humanistycznych i społecznych z przyrodniczymi oraz wiedzami tubylczymi" (Domańska 2013a: 14). "Zwrot ekologiczny" splata się więc z kontestacją. Słowa 'posthumanizm' czy 'postantropocentryzm' akcentują bowiem negatywny punkt wyjścia, co wyraża stosowany po częstokroć przedrostek 'post-‘. Podkreśla on zmianę polegającą na zrównaniu człowieka w świecie z innymi bytami, a tym samym jego niepomierne pomniejszenie. Człowiek jest cząstką ekosystemu niejako na równych prawach z wszystkimi innymi tworami przyrody. Zakwestionowaniu podlega też eurocentryzm, europejskość jako sygnatura wielowiekowej kultury, tradycji wzorcowej dla kultur pozaeuropejskich, przy szczególnie znamiennym dla humanistyki ekologicznej dowartościowaniu „wiedzy tubylczej”, „naturalnej", dotąd deprecjonowanej, stereotypowo wiązanej z prymitywizmem formy i treści. Po lekturze szkiców ekohumanistów pozostaje wrażenie, że ten właśnie rodzaj wiedzy (i kultury) wysunięto na plan pierwszy. Dla humanistyki ekologicznej liczy się bowiem niezhierarchizowana wizja świata,

3 Ten szkic traktuję jako źródłowy i podstawowy dla podjętej tematyki; podawane w nim tezy były wielokrotnie streszczane na użytek innych artykułów o tematyce ekologicznej. 
a to dlatego, że każda porządkująca rzeczywistość hierarchia - „piramidalna metafora rzeczywistości” - odbierana jest negatywnie. Rzeczywistość w omawianym szkicu obrazuje ahierarchiczna "metafora splątanych relacji, networków, sieci, a także asamblaży, kolektywów, pokrewieństwa, towarzystwa i wspólnot" (Domańska 2013a: 27) ${ }^{4}$. Jest to całościowy obraz przestrzeni nie znającej żadnych czasoprzestrzennych determinant. Stanowi ona świat „wspólny”, ale - jak wyjaśnia Domańska - „rozumiany nie w kategoriach globalizacji, ale w perspektywie planetarnej i kosmicznej, a także molekularnej" (Domańska 2013a: 15). Ostatnie trzy przymiotniki uszczegóławiające w przytoczonym tu szeregowym dookreśleniu są niezwykle ważne dla ekohumanistycznych propozycji, ponieważ sugerowany przez nie model świata pozostaje na poziomie gęstej, splątanej sieci, tworzącej „żywy system planety”. Partycypacja w nim właśnie jest jednym z elementów ekohumanistycznej mentalności. Humaniści ekologiczni apelują o radykalną przemianę myślenia, która wyrazi się w wytworzeniu świadomości poczucia związku człowieka z innymi bytami na poziomie molekularnym. „Człowiek jest wielogatunkową hybrydą, bytem metawspólnotowym, który znajduje się w stałym procesie symbiotycznego stawania się i ko-ewolucji” i dalej: „Poziom rozważań bio-mikro-neuro pokazuje, że ludzie, rośliny i zwierzęta nie różnią się tak zasadniczo" (Domańska 2013a: 27). Na ile możliwe jest ukierunkowanie myślenia ludzkiego w tym kierunku, trudno przewidzieć. Podobnie zresztą jak i inny, pozornie prosty postulat omawianej tu metodologii, a mianowicie gdy mowa o „Pojęciu

4 Nie sposób nie skojarzyć proponowanego tu obrazu rzeczywistości z metaforą kłącza, poprzez którą tożsamość zostaje wyparta przez różnicę, kosmos przez chaosmos (czy też chaosmozę); metafora kłącza zastępuje nośną znaczeniowo metaforę korzenia jako wspólnej podstawy (Deleuze, Guattari 1988). Pozostaje jednak pytanie, czy metafora kłącza ma li tylko opisywać współczesną rzeczywistość w jej różnych wymiarach, czy też ma sens normatywny. życia opartego na węglu (carbonbased life), [które] staje się podstawą idei ko-substancjalnej identyfikacji ziemskich form życia”, jak również odwoływanie się „do etyki solidarności i szacunku wobec wszelkich form życia, także nieożywionych organicznie (na przykład rzeczy, skały)" (Domańska 2013a: 16-20). Ostatnia ze zgłoszonych idei nie jest nowa, jak zresztą i wiele pozostałych głoszonych przez humanistykę ekologiczną. Od dawien dawna bowiem w edukacji rodzinnej i szkolnej oraz poprzez podstawowe reguły kultury życia społecznego przestrzegano szacunku człowieka dla przyrody nieożywionej, a tym bardziej - ożywionej, zwracając uwagę nie tylko na moralne zobowiązanie do nieniszczenia jej w jakiejkolwiek formie, lecz do troski o nią, do ochrony dziedzictwa natury, widząc w świadomym jej niszczeniu moralne zło (Dzwonkowska 2013). Literatura piękna, będąc sejsmografem poruszeń ludzkich dusz czulszym niż socjologiczne, obiektywizujące badania społecznych zachowań, nawet jeśli obrazuje niszczenie środowiska przyrodniczego, nawet jeśli zdiagnozuje jego przyczyny, nie afirmuje tego faktu. Zwykle bezpośrednio lub pośrednio staje po stronie niszczonej przyrody, skrzywdzonego zwierzęcia czy zdeformowanego krajobrazu. Bierze w obronę człowieka, którego owo zło zniszczenia środowiska najbardziej dotyka i który przez to fizycznie i duchowo cierpi. Paradoksalnie - człowiek jako główny sprawca kryzysu ekologicznego jest też główną jego ofiarą (Łepko 2016).

Człowiek postawiony wobec natury, wchodzi w jej świat wraz ze swoją historycznie zmienną kulturą, tworzoną na miarę współczesnej mu cywilizacji. Kulturę europejską ukształtowała tradycja religijna judaizmu i chrześcijaństwa, w których człowiek zgodnie z Biblią - jest traktowany jako panujący nad dziełem stworzenia. Niemniej ta rola nigdy nie sprowadzała się do dominacji, rozumianej jako nieograniczona wszechwładza człowieka nad naturą, bo wówczas wszedłby on w rolę uzurpatora, odrzucającego elementarne moralno-religijne nakazy wynikające z Biblii, z Dekalogu. 
Tymczasem „zwrot ekologiczny” w badaniach nad literaturą (i kulturą) polega na defensywnym wręcz odwróceniu się od tej tradycji myślenia ${ }^{5}$ (do tego problemu powrócę w dalszej części rozważań). W imię biocentryzmu człowiek postrzegany jest w niej jako byt li tylko biologiczny, jako opresor względem natury, reprezentujący postawę, jak się to określa, „szowinizmu gatunkowego" (Domańska 2013a: 29). Jest to interesujący aspekt w humanistyce ekologicznej, określany perswazyjnie jako „promowanie innego sposobu widzenia świata”, opartego „na myśleniu relacyjnym, które podkreśla wzajemne związki, współzależność, współbycie i współ-życie naturo-kultury, człowieka i środowiska, bytów i istot ludzkich i nie-ludzkich" (Domańska 2013a: 15). Można powiedzieć, że myślenie kategoriami relacji nie jest niczym nowym. Wyrażone wszakże językiem współczesnego dyskursu ekologicznego budzi nieco wątpliwości. Co bowiem oznacza przywoływana w szkicu Domańskiej idea „pasywnej natury pojmowanej jako gotowy do wykorzystania przez człowieka zasób" (Domańska 2013a: 22)? Natura nie jest „pasywna”. Warto w tym miejscu wspomnieć o parze komplementarnych, filozoficznych pojęć: natura naturata i natura naturans, ze znaczącą przewagą kategorii drugiej, jako adekwatnej nawet do potocznego doświadczenia osoby ludzkiej.

W przedstawianych koncepcjach znać także ślady słownictwa feministycznego. Ewa Domańska twierdzi bowiem, że „szeroko rozumiane myślenie ekologiczne, nastawione jest krytycznie wobec tradycyjnego paradygmatu opartego z jednej strony na mechanicystycznej nauce, a z drugiej na

5 Kronenberg podając wyznaczniki owego „zwrotu” pisze o „krytycznym odczytaniu tradycji starożytnej, judeochrześcijańskiej, a także współczesnej: modernistycznej i postmodernistycznej" (Kronenberg 2014: 298). Cytuje też opinię, że „W swojej działalności de nomine i de facto Kościół chrześcijański w żadnej mierze nie starał się wzmocnić więzi człowieka z Naturą" (Skolimowski 1999: 94; Kronenberg 2014: 301). Problem ten szeroko analizuje Sadowski 2015. patriarchalnych wartościach (patriarchalizm rozumiany jest tutaj jako dominacja człowieka nad naturą)" (Domańska 2013a: 19). Rys antypatriarchalny, znamienny dla modelowego dyskursu ekohumanistycznego, jest argumentem za eklektycznym charakterem tegoż dyskursu i właściwego mu zbioru pojęć, także za eklektycznością tego projektu, co zresztą implikują podane przez Domańską opisowe definicje humanistyki ekologicznej jako „wielogatunkowej teorii nauk humanistycznych i społecznych" (Domańska 2013a: 28).

Zgodnie z pierwszą definicją biohumanistyka, by i tę nazwę przywołać, jest to „multidyscyplinarna dziedzina badań, której celem jest integrowanie i niehierarchiczne traktowanie nauk humanistycznych i przyrodniczych, wiedzy zachodniej, wschodniej i tubylczej. Podstawę humanistyki ekologicznej stanowi ontologia związków promująca zarówno ludzkie relacje międzykulturowe, jak i związki międzygatunkowe"; uzupełnienie definicji brzmi nieobco, a mianowicie: „Humanistyka ekologiczna głosi konieczność podporządkowania się prawom ekologicznym i ujęcia ludzkości jako części większej całości żyjącego systemu. Odwołuje się ona do etyki szacunku, wzajemności i międzygatunkowej solidarności, która ma istotne znaczenie dla przemyślenia idei sprawiedliwości społecznej i uczynienia jej otwartą na byty nie-ludzkie" (Domańska 2013a: 21).

Druga zaś definicja, podana w innym artykule Domańskiej, nie uchylając wcześniej podawanych założeń, poszerza zakres zainteresowań badawczych, stąd twierdzenia, że pod pojęcie humanistyki ekologicznej podpada „na przykład zainteresowanie klimatem, środowiskiem, morzami, zwierzętami czy rzeczami”, choć jej głównym celem jest „pisanie głębokiej historii bardzo długiego trwania" (Domańska 2013b: 225). Autorkę wszakże interesuje nie tyle sama powtarzalność podejmowanych tematów przyrodniczych, ile „stawianie [ich] w zupełnie innej niż wcześniej ramie interpretacyjnej, którą dostarcza uważana za nowy paradygmat posthumanistyka czy humanistyka 
nieantropocentryczna, humanistyka ekologiczna (środowiskowa czy zrównoważonego rozwoju) i biohumanistyka, a także wykorzystywanie ostatnich osiągnięć biologii i neuronauk, [które] stymuluje odmienny dobór i sposób stawiania problemów, inny kwestionariusz pytań badawczych, a często wybór odmiennych typów źródeł i metod badań" (Domańska 2013b: 225). Pojawia się tu problem narzędzi badawczych dla literaturoznawstwa, szczególnie narzędzia zwanego w badaniach filologicznych 'ramą interpretacyjną'. Ryszard Tokarski określa tę ramę jako przekroczenie znaczenia słowa i jego miejsca „w systemie językowym bądź w strukturze tekstu”, a „wiąże się z konwencjami kulturowymi, ludzką wiedzą i doświadczeniem", rama interpretacyjna według Tokarskiego - to "pewna struktura konceptualna, scena, jaka na mocy konwencji przez dane słowo (lub grupę słów) jest aktywowana" (Web-o1). Bez wątpienia projekt humanistyki ekologicznej jest ramą interpretacyjną w przytoczonym tu rozumieniu.

\section{Lektury (eko)interpretacyjne}

Weryfikacją przedstawionej pokrótce ekohumanistycznej metodologii badań literaturoznawczych jest jej przetestowanie, czego efektem jest pojawienie się w obiegu naukowym interpretacji konkretnych utworów literackich bądź ich fragmentów pozostających pod czytelnym wpływem metodologicznych przeświadczeń humanistyki ekologicznej i kształtowanej przez nią świadomości. Jednym z charakterystycznych określeń praktyki interpretacyjnej jest wspomniana wyżej metafora, określająca rodzaj tej aktywności badawczej jako „zielone czytanie". Założenia metodologiczne można by zaakceptować, gdyby nie praktyka interpretacyjna, polegająca na potraktowaniu ogólnych idei ekohumanistycznych koncepcji jako porządku nadrzędnego wobec tekstu literackiego. Tego rodzaju praktyka może niekiedy oznaczać pójście w kierunku nadinterpretacji, a nawet i błędu poznawczego.

Oczekiwania powyższe, przetestowania metodologicznej koncepcji „zielonego czytania”, spełnia szkic Dariusza Piechoty o naturalistycznej powieści Antoniego Sygietyńskiego $\mathrm{Na}$ skałach Calvados, opublikowanej w roku 1884, powieści chętnie komentowanej przez historyków literatury. Piechota podejmując badania, czyni to świadom eksperymentalności własnych poczynań analityczno-interpretacyjnych. Prowadzi tak interpretację, że jasno z niej wynika respekt względem wskazanej przez Domańską „nowej ramy interpretacyjnej”. Autor konsekwentnie przestrzega punktu widzenia: ekohumanistycznego, postantropocentrycznego, z wizją człowieka jako opresora wobec natury, czyli dewastatora środowiska naturalnego. Człowiek ów jest kimś, kto przysparza naturze wielkich cierpień. Zresztą już na wstępie badacz deklaruje odrzucenie "antropocentrycznej wizji rzeczywistości", chce bowiem zinterpretować powieść „z perspektywy biocentrycznej, zgodnie z którą przyroda odgrywa prymarną rolę we wspólnym ekosystemie" (Piechota 2015: 191). Człowiek zaś, czyli bohater literacki powieści Sygietyńskiego, jest wpisany w „nadmorski ekosystem” (bo tak określa się świat przedstawiony w powieści), skonfrontowany z symboliką "olbrzymich skał”. Argumentem na postantropocentryzm (i biocentryczność) powieściowej narracji mają być zapowiadające prymat przyrody metatekstowe treści tytułu ( $\mathrm{Na}$ skałach Calvados) i podtytułu (Powieść z życia normandzkich rybaków). Zgodnie z tą kolejnością rola człowieka-rybaka, przypisywanego przez autora szkicu do „kultury patriarchalnej" (Piechota 2015: 196), ulega uszczupleniu. Jest to teza trudna do przyjęcia, jeśli mamy na uwadze choćby początek powieści, którą Sygietyński obyczajem pisarzy drugiej połowy XIX wieku rozpoczyna od zarysowania miejsca powieściowych wydarzeń, ważnego w egzystencji normandzkich rybaków. Początek powieści brzmi następująco: „Dniało. Złote promienie wschodzącego słońca przesuwały się po przejrzystych falach Lamanszy i migoczącym blaskiem drżały na szczytach wspinającej się wody. Wiatr wiał od wschodu i zimnym, przejmującym tchnieniem, 
strychował po płótnach wysmukłej Eufra$z j i$, która powoli ciągnęła za sobą wielki włok rybacki po piaszczystym dnie morza" (Sygietyński 1884: 1) ${ }^{6}$. Warto zaznaczyć, że w tym samym segmencie tekstu, do którego przynależy przytoczony opis morza, pojawia się postać „młodego wyrostka”, stojącego na pokładzie „Eufrazji”, który „trzymając linę w ręku, gwizdał pod nosem tęskną piosenkę rybacką" (Sygietyński 1884: 1). Powieść Sygietyńskiego eksponuje losy człowieka, losy ludzkie, które zachodzą w świecie natury i trudne do utrzymania jest założenie Piechoty o nieantropocentrycznym punkcie widzenia narratora powieści ${ }^{7}$. Można przyjąć jedną z tez Piechoty, że w „przestrzeni nadmorskiej miejscowości granice między światem natury a kultury zacierają się", i dalej: że „Domy mieszkańców, porośnięte porostami oraz mchami, niejednokrotnie »wtapiają się« w pejzaż ekosystemu, co podkreśla pierwotność przyrody wobec cywilizacji” (Piechota 2015: 193). Biorąc jednak pod uwagę całość kompozycyjną tej książki, widać, że Sygietyński konstruuje powieściowy pejzaż zgodnie z regułą ludzko-przyrodniczego zróżnicowania i że granice obydwu światów zaznaczają się wyraźnie, mimo stylistycznych zabiegów animalizacji środowiska ludzkiego. Ludzkie w tej powieści pozostaje ludzkim, a nie-ludzkie nie-ludzkim. To prawda, że „Człowiek egzystujący w ekosystemie uwikłany jest w sieć wzajemnych relacji ze światem natury" (Piechota 2015: 194) i że literatura nieustannie o tym pamięta, ale - nie jest to nowa teza ekoposthumanistyki, jeśli pamięta się badania literaturoznawcze nad Panem Tadeuszem Adama Mickiewicza czy nad Chłopami Władysława St. Reymonta. W utworach tych osoba ludzka jest „cząstką ekosystemu, w skład którego wchodzą zwierzęta, rośliny,

6 W cytatach z powieści Sygietyńskiego pisownię uwspółcześniono.

7 Błędem wszelkich analiz, w tym analiz dzieła literackiego, jest kierowanie się zewnętrznymi wobec niego schematami interpretacyjnymi, jak choćby $\mathrm{w}$ tym przypadku: ostrym przeciwstawianiem sobie antropocentryzmu biocentryzmowi. minerały etc." (Piechota 2015: 195), jest to cząstka, najważniejsza, artystycznie eksponowana. Zabiegi zaś animalizujące u Sygietyńskiego są uświęconą wręcz praktyką literacką i jedną z możliwych ścieżek badawczych, dobrze zresztą spenetrowaną (Abramowska 2010).

Z powieści Na skatach Calvados Piechota wyprowadza wniosek, iż „Na skutek pasożytniczej działalności człowieka ekosystem morski uległ destrukcji” (Piechota 2015: 198). Trudno się z tym zgodzić, bo powieściopisarz podkreśla raczej sytuację „długiego trwania" owego ekosystemu, jego niezniszczalność. Powstaje też pytanie, czy naprawdę jest tak, że Sygietyński - jak utrzymuje autor interpretacji - „kwestionuje antropocentryczną wizję rzeczywistości: natura w powieści pełni rolę nadrzędną wobec kruchej egzystencji człowieka" (Piechota 2015: 193). Oczywiście prawdą jest, o czym pisze Piechota, że życie rybaków normandzkich, tak jak i życie człowieka, w mniejszym lub większym stopniu podlega rytmowi życia natury. Pisarz trafnie uchwycił „zależność od świata natury" (Piechota 2015: 198), takie jest doświadczenie rybaków i doświadczenie każdego człowieka, niemal codzienne. Ale już stwierdzenia, że rybacy „traktują morze w sposób przedmiotowy, pogrążając się nieustannie w nadmiernej konsumpcji", że „kierują się głównie egoistycznymi pobudkami - chęcią wzbogacenia się" (Piechota 2015: 198) są wielce dyskusyjne, pochodzące nie tyle od narratora powieści, ile od autora szkicu. Z całą pewnością dokonane przez Piechotę omówienie powieści Sygietyńskiego ukierunkowuje ekohumanistyczna „rama interpretacyjna”, o której pisała Domańska. Powstaje jednak pytanie, czy dokonywane w powieści połowy ryb można interpretować w kategoriach „dewastacji ekologicznej" (Piechota 2015: 197) ${ }^{8}$ i czy

8 Jest to określenie stosowane $\mathrm{w}$ strategiach „zielonego czytania”; dla Kronenberg humanistyka ekologiczna wynika ze współczesnej „dewastacji środowiska przyrodniczego", na którą odpowiedź winna dać literatura i kultura (Kronenberg 2014: 294). 
takie publicystyczne stwierdzenia pozostają jeszcze w obszarze badań literaturoznawczych. I czy Sygietyńskiego na pewno należy wpisać do grona "myślicieli ekokrytycznych” (Piechota 2015: 199) ${ }^{9}$. Jest bowiem i tak, że „Tekst dopuszczający ograniczoną liczbę interpretacji zbliża się ku tekstowi nieartystycznemu i traci specyficzną artystyczną długowieczność" (Łotman 1984: 103), ale czy tego rodzaju poszerzenie spectrum możliwości interpretacyjnych jest uzasadnione samym tekstem.

Przedstawiona przez Dariusza Piechotę interpretacja powieści Sygietyńskiego z pewnością odzwierciedla przekonania twórców humanistyki ekologicznej. Na ile utrwalą się one w badaniach literaturoznawczych, czas pokaże.

\section{Treści preekologiczne i proekologiczne literatury}

„Zielone pisanie” można natomiast z powodzeniem odnieść do praktyki pisarskiej, do treściowej zawartości samych dzieł literackich, gdyż, o czym pisałam wyżej, humanistyce ekologicznej trudno odmówić słuszności, ponieważ poszerza ona spojrzenie na literaturę, na dzieło literackie. Za cytowanym już Łotmanem, można rzec, że „tekst artystyczny można rozpatrywać jako tekst wielokrotnie zakodowany" (Łotman 1984: 88) i analiza utworu może odsłonić także treści ekologiczne. W odniesieniu do dzieł historycznie wcześniej powstałych można je nazwać treściami preekologicznymi, czy też antycypującymi podejście ekologiczne, opisywane we współczesnej humanistyce. Literaturze, i to od czasów niepamiętnych, właściwe jest bowiem nastawienie na środowisko przyrodnicze, na zachowanie

9 Zob. także szkic Zielona macewa (Kłos 2017), $\mathrm{z}$ interesującym eksperymentem myślowym - wyobraźniowego widzenia zielonej macewy w martwej, obumarłej, „obciążonej piętnem cmentarzyska" przestrzeni Auschwitz-Birkenau (Kłos 2017: 166); figura nieobecnej macewy jako zielonego drzewa życia („zielonej ramy” interpretacyjnej) jest metaforą długotrwałej pamięci o zmarłych, którzy w niemieckim obozie doznali wielkich cierpieniach. jego stanu poprzez ochronę przyrody. To w dziełach literackich najbardziej przekonywająco jest demonstrowana wrażliwość podmiotu literackiego na kategorię „ekologiczności”. Znakiem obecności natury są i te obrazy literackie, które da się powiązać, na przykład, z czterema żywiołami, ogniem, wodą, powietrzem i ziemią, współtworzącymi świat uporządkowany lub popadający w chaos, gdy w konstytuowaniu porządku lub chaosu rzeczywistości literackiej przyroda bierze czynny udział.

Koncepcja świata jako bujnie rozkwitającego ogrodu, obraz człowieka umieszczonego w tym ogrodzie, przekonanie, że Bóg jest stwórcą tego świata-ogrodu uwyraźnia się w dziełach literackich, filmowych i muzycznych tak często, że odbiorca niemal uodpornia się na tegoż świata nadprzyrodzony wymiar. Jeśli jednak analizować główne teksty humanistyki ekologicznej, to zastanawia w nich fakt odwoływania się do duchowości enigmatycznej, rozumianej jako „postsekularna”, oznaczająca „powrót duchowości, eklektyzm religijny, pozainstytucjonalne formy praktyk religijnych, neopogaństwo" (Domańska 2014a: 14). Zarazem jednak pomija się transcendentny sens bycia człowieka i przyrody, ten wymiar natury, który stanowi - by nawiązać do formuł Gadamera - „metafizyczne odniesienie do boskiego nieskończonego ducha" (Gadamer 1993: 436). Nie uwzględnia się, a może i wręcz ignoruje, różnorakie sakralizacje ujawniające się w literackich opisach przyrody, natomiast radzi się, by wyjaśnień zjawisk przyrodniczych, w dziele literackim zwykle o statusie owianym tajemnicą, niewytłumaczalnych, poszukiwać w „wiedzy tubylczej”, lokalnej jako najbardziej wiarygodnej. Marginalizuje się natomiast biblijne Objawienie, gdyż w ekohumanistycznej wizji świata i człowieka brakuje Boga Stworzyciela jako arché rzeczywistości stworzonej. W teoretycznej refleksji nad literaturą podpadającą pod pojęcie „zielonego pisania” nie ma choćby ogólnikowego zaznaczenia poglądu, że w judaizmie i chrześcijaństwie (a większość utworów literatury polskiej powstała 
w zasięgu oddziaływania obu) „religia jest realną i dynamiczną relacją człowieka do osobowego Absolutu" (Zdybicka 1984: 271). Jednym z przykładów takiej literatury jest Franciszkowa radosna miłość do stworzenia, przekonywająco wyrażona w Kwiatkach św. Franciszka czy w popularnej tegoż świętego Pieśni słonecznej (Canticum Fratris Solis, znanej pod tytułem Pochwała stworzenia). Pieśń tę rozpoczyna wzniosła, modlitewna fraza: „Najwyższy, wszechmogący, dobry Panie, Twoja jest sława, chwała i cześć, i wszelkie błogosławieństwo", zaś poszczególne zwrotki zaczynają się od retorycznego powtórzenia: „Pochwalony bądź, Panie mój” (Web-02). Podmiot pieśni trwa w postawie fascynacji pięknem stworzenia, gdy poprzez figurę metonimii odnosi się do całości dzieła stworzenia, mówiąc o „szlachetnym bracie słońcu”, o bracie wietrze, o siostrze wodzie, "siostrze naszej, matce ziemi” (Web-o2). Można przyjąć, że w świetle „ekologicznej” poezji Świętego z Asyżu współczesny dyskurs ekohumanistyczny jest konstrukcją słowną alternatywną wobec dyskursu genezyjskiego, wpisującą się w obszar myśli postchrześcijańskiej.

Treści literackie, nazwane wyżej preekologicznymi, w literackim obrazowaniu przyrody ściśle splatają się z treściami proekologicznymi. Człowiek w dziele literackim pozostaje względem przyrody w relacji nadrzędno-podrzędnej jako ten, który winien umiejętnie panować nad stworzonym światem tak, żeby ów świat rozkwitał. Przyjazny stosunek do przyrody jest jedyną postawą akceptowaną $w$ literaturze, natomiast przejawy wrogości wobec niej, choćby banalne, nie mówiąc o czynach rozmyślnie destrukcyjnych, sytuowane są w sferze antywartości. Tę ambiwalentną postawę, pochwały i potępienia, uwidacznia proza Zofii Kossak, szczególnie zaś jej książka Nieznany kraj (1932), obfitująca w nadzwyczaj piękne opisy przyrody. Jednym z pierwszych jest uwznioślony opis dzikiej przyrody, boru, który „stał ogromny, milczący, niezdeptany, nieprzebyty, wzmocniony gęstym podszyciem bujnie wzrosłym na wilgotnej ziemi" (Kossak 2018:
15). Tę bujną, świeżą zieleń mają w wielkim poszanowaniu „miejscowi Ślęzanie”. W prozie Kossak przyroda jawi się jako natura naturans, ku której człowiek zwraca się niemal nabożnie, w postawie podziwu, akceptacji i afirmacji. Ilustracją zburzenia ładu "nieprzebytej puszczy” jest wtargnięcie do boru niemieckich najeźdźców, obcych wojsk, które płoszą „wrzawą zwierza leśnego i ptactwo", sam zaś dowódca wojsk, cesarz niemiecki Henryk II, ukazany jest jako postać negatywna, „zły jak noc, gniewny jak szatan” (Kossak 2018: 16). Narrator zaznacza, że oddziały wysyłane przez niego na zwiady, "ginęły bez śladu, jak gdyby je wchłonął bór. Gdzie się podziewa margrabia Bernard, ciągnący od północy z Lucicami? Co poczyna czeski książę Ołdrzych, idący z południa? Nieprzebyta puszcza zwarła się kręgiem, nie przepuszczając żadnej wiadomości” (Kossak 2018: 19). Doznawszy zła, natura działa milcząco, a jej milczenie jest znakiem ostrzeżenia przed klęską tej wyprawy wojennej. Henryk II nie rozumie sensu tego znaku nawet wówczas, gdy jego wojska po zwarciu z wojskami Bolesława Chrobrego wyginęły. Ocalały tylko „niedobitki cesarskie”, które $\mathrm{z}$ „nadodrzańskiej runi [...] rzuciły się wpław uciekać. Woda je zniosła, porwała chyżo w mrok" (Kossak 2018: 25).

Jeśli człowiek dopuszcza się zła wobec przyrody, to owo zło literatura postrzega w kategoriach moralnego występku, zaciągania winy moralnej w każdej sytuacji bezmyślnego zabijania zwierząt, wycinania czy palenia lasów, zanieczyszczenia wód. W takich realiach podmiot literacki, baczny obserwator zmian w środowisku naturalnym, z bólem odnotowuje zatratę tożsamości danego miejsca. Harmonijna dwuprzestrzeń, Nieba i Ziemi, wspólnota ludzi pozostających z przyrodą w relacji wzajemnego szacunku, a niekiedy nawet przyjaźni, zamienia się $\mathrm{w}$ tragiczne theatrum mundi, w którym dopełnia się wspólny los - człowieka i natury. 


\section{Bibliografia}

Abramowska J., 2010, Pisarz w zwierzyńcu, Wydawnictwo Poznańskie, Poznań.

Anonim tzw. Gall, 1965, Kronika polska, tłum. R. Grodecki, Zakład Narodowy im. Ossolińskich, Wrocław.

Deleuze G., Guattari F., 1988, Kłącze, tłum. B. Banasiak, Colloquia Communia, nr 1-3, 221-238.

Dołęga J.M., 20o6a, Ekofilozofia - nauka XXI wieku, Problemy Ekorozwoju, nr 1, 17-22.

Dołęga J.M., 20o6b, Sozologia systemowa - dyscyplina naukowa XXI wieku, Problemy Ekorozwoju, nr 1, 11-23.

Domańska E., 2013a, Humanistyka ekologiczna, Teksty Drugie, nr 1-2, 13-32.

Domańska E., 2013b, Wiedza o przeszłości - perspektywy na przyszłość, Kwartalnik Historyczny, nr 2, 221-274.

Dzwonkowska D., 2013, Virtue and vice in environmental discourse, Studia Ecologiae et Bioethicae, nr 4, 61-76.

Gadamer H.-G., 1993, Prawda $i$ metoda. Zarys hermeneutyki filozoficznej, tłum. i wstęp B. Baran, Inter Esse, Kraków.

Kłos A., 2017, Zielona macewa, Teksty Drugie, nr 2, 166-174.

Korwin-Piotrowska D., 2001, Problemy poetyki opisu prozatorskiego, Towarzystwo Autorów i Wydawców Prac Naukowych Universitas, Kraków.

Kossak Z., 2018, Nieznany kraj, Instytut Wydawniczy Pax, Warszawa.

Kronenberg A., 2014, Geopoetyka jako przyktad zielonego czytania i pisania, Teksty Drugie, nr 5, 294-320.

Łepko Z., 2016, Antropological Aspect of the О1коб Crisis, w: Return to the Oıкоб. Ways to Recover Our Common Home, ed. J.I. Kureethadam, Z. Łepko, R.F. Sadowski, LAS Roma, 25-39.
Łotman J., 1984, Struktura tekstu artystycznego, tłum. A. Tanalska, Państwowy Instytut Wydawniczy, Warszawa.

Piechota D., 2015, „Na skatach Calvados” Antoniego Sygietyńskiego w świetle humanistyki ekologicznej, Annales Universitatis Mariae Curie-Skłodowska, 191-200.

Sadowski R.F., 2015, Filozoficzny spór o rolę chrześcijaństwa w kwestii ekologicznej, Towarzystwo Naukowe Franciszka Salezego, Warszawa.

Skolimowski H., 1999, Wizje Nowego Millenium, Wydawnictwo EJB, Kraków.

Sławiński J., 1992, O opisie, w: tenże, Próby teoretycznoliterackie, Warszawa.

Sygietyński A., 1884, Na skatach Calvados. Powieść z życia normandzkich rybaków, Księgarnia Lesmana i Swiszczowskiego, Warszawa.

Sztumski W., 1996, Zasady myślenia ekologicznego w doktrynie enwironmentalizmu, w: Dylematy ekologii, red. I. Butmanowicz-Dębicka, J, Jaśtal, [s.n.], Kraków.

Wróblewski Z., 2004, Uwagi o rodzinie znaczeń pojęcia 'ekologia', „Państwo i Społeczeństwo” nr 2, 153-162.

Wysłouch S., 1998, Od Lessinga do Przybosia. Teoria i kompozycja opisu, w: „Problemy teorii literatury”, Seria 4, Zakład Narodowy im. Ossolińskich, Wrocław.

Zdybicka Z., 1984, Człowiek i religia. Zarys filozofii religii, Redakcja Wydawnictw KUL, Lublin.

(Web-01) Tokarski R., 2006, Pola znaczeniowe i ramy interpretacyjne - dwa spojrzenia na jezzyk, LingVaria, nr 1, http://www.lingvaria.polonistyka.uj.edu. $\mathrm{pl} /$ documents/5768825/a58dba4d-11bb-4e4d-b4dd-9997228e2ad8, dostęp: 20.10.2018.

(Web-02) Franciszek z Asyżu, Pieśń słoneczna albo Pochwała stworzeń, http://www.ultramontes.pl/ sw_franciszek_canticum_fratris_solis.pdf, dostęp: 12.11.2018. 


\section{"Green Writing", "Green Reading": Ecological humanities as a literary research project}

\section{Abstract}

The article discusses one of the new methodologies in literary studies i.e. ecological humanities. Referring to theoretical texts, the author critically examines their main ideas. In this spirit, she comments on the interpretation of literary works based on the methodology offered by bio-humanities, focusing on the sketch on the novel "On the Rocks of Calvados" (1884) by Antoni Sygietynski. Author presents "green writing" as common practice among authors of literary works and puts forward a hypothesis that literature might be ascribed with a precursory attribute in the field of ecology.

\section{Keywords}

ecological humanities, bio-humanities, ecological paradigm in literary studies 